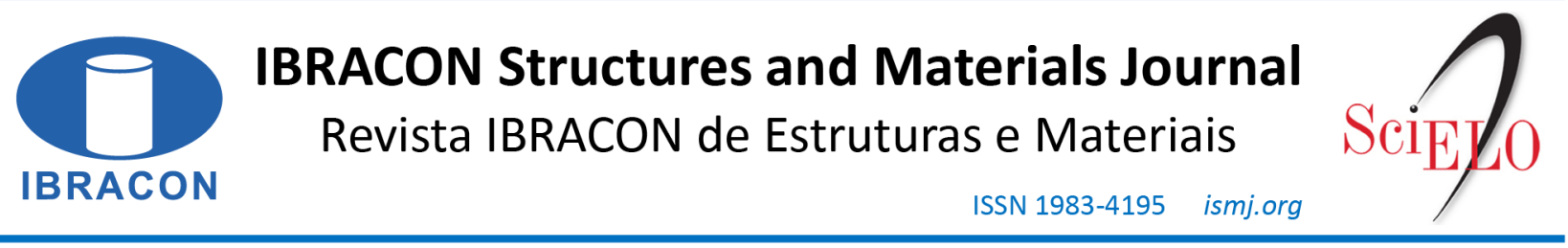

ORIGINAL ARTICLE

\title{
Experimental investigation on structural concrete masonry in fire: emphasis on the thermal behavior and residual strength
}

\section{Análise experimental sobre alvenaria estrutural de blocos de concreto em situação de incêndio: ênfase no comportamento térmico e na resistência residual}

\author{
Davi Fagundes Leal ${ }^{\mathrm{a}, \mathrm{b}}$ \\ Rafael Henrique Dupim ${ }^{\mathrm{a}}$ (D) \\ Jorge Munaiar Neto ${ }^{\mathrm{a}}$ \\ Márcio Roberto Silva Corrêa ${ }^{\mathrm{a}}$
}

${ }^{a}$ Universidade de São Paulo - USP, Escola de Engenharia de São Carlos, Departamento de Engenharia de Estruturas, São Carlos, SP, Brasil bInstituto Federal de Educação, Ciência e Tecnologia Fluminense, Campos dos Goytacazes, RJ, Brasil

Received 17 June 2020

Accepted 15 October 2020

\begin{abstract}
This paper aims to analyze the thermal behavior and residual mechanical properties of concrete hollowblocks structural masonry and its component materials in fire situation using experimental investigation. Compression tests were carried out on blocks, prisms and small walls at room temperature and after being exposed for 70 minutes to the ISO 834 Standard Fire. The test at high temperatures was run using a furnace powered by natural gas and instrumented with thermocouples to measure temperatures in the specimens. The influence of the initial concrete strength on masonry behavior was evaluated considering the use of blocks with different strengths at room temperature. In addition, exposure to fire was also investigated considering masonry elements with no coverings and submitted to two different fire exposure conditions: one or both sides. The results indicate a substantial loss in the masonry load capacity at high temperatures, especially in cases of fire exposure on both sides, where the residual compressive strength resulted, on average, between $20 \%$ and $27 \%$ for the blocks and approximately $14 \%$ for prisms and small walls. Its performance with fire heating up on only one face is much higher, with an average residual masonry strength equal to $46 \%$ compared to its strength at room temperature. The obtained results are also useful for evaluating masonry regarding the integrity and thermal insulation criteria, the latter achieved with little over 60 minutes of testing.
\end{abstract}

Keywords: structural masonry, concrete, fire, residual strength, thermal behavior.

Resumo: O presente trabalho tem como objetivo investigar, por meio de análises experimentais, o comportamento térmico e as propriedades mecânicas residuais da alvenaria estrutural de blocos vazados de concreto e seus materiais componentes em situação de incêndio. Foram realizados ensaios de compressão com elementos representativos da alvenaria (blocos, prismas e pequenas paredes) antes e após serem expostos por 70 minutos ao Incêndio-Padrão proposto na ISO 834-1:1999, o qual foi aplicado por meio de um forno a gás natural instrumentado com termopares para a medição das temperaturas em seu interior e também nos corpos de prova. A influência da resistência inicial do concreto no comportamento da alvenaria foi avaliada considerando-se blocos com diferentes resistências características à temperatura ambiente. Além disso, a forma de exposição ao incêndio foi também investigada, sendo ensaiados elementos sem revestimento e com fogo atuando em uma ou em ambas as faces. Os resultados apontam significativa perda de capacidade resistente da alvenaria quando em temperaturas elevadas, principalmente nos casos em que o fogo atua em ambas as faces, onde a resistência residual à compressão resultou entre $20 \%$ e $27 \%$ para os blocos e em torno de $14 \%$ para prismas e pequenas paredes, em média. Seu desempenho com fogo atuando em apenas uma face se mostra bem melhor, com resistência residual média da alvenaria igual a $46 \%$ em relação à sua resistência à temperatura ambiente. Os resultados encontrados também são úteis para a avaliação da alvenaria quanto aos critérios de estanqueidade e isolamento térmico, este último atingido com pouco mais de 60 minutos de ensaio.

Palavras-chave: alvenaria estrutural, concreto, incêndio, resistência residual, comportamento térmico.

Corresponding author: Davi Fagundes Leal. E-mail: daviusp@sc.usp.br

Financial support: This study was funded by the São Paulo Research Foundation (FAPESP - grant number 2017/20255-4). Author Rafael Henrique Dupim received a research scholarship from the National Council for Scientific and Technological Development (CNPq).

Conflict of interest: Nothing to declare. 
How to cite: D. F. Leal, R. H. Dupim, J. Munaiar Neto, and M. R. S. Corrêa, "Experimental investigation on structural concrete masonry in fire: emphasis on the thermal behavior and residual strength," Rev. IBRACON Estrut. Mater., vol. 14, no. 4, e14408, 2021,

https://doi.org/10.1590/S1983-41952021000400008

\section{INTRODUCTION}

Structural masonry elements are an assembly of blocks bonded together with mortar joints. In this type of construction, in addition to being an important part in the architectural layout, walls also fulfill the structural function. Therefore, structural masonry buildings generally do not need columns and beams as slabs consider masonry walls as support. This construction system has been widely used in many countries, especially in Brazil, where it can be found from small houses to multi-storey buildings with about twenty floors, as presented in Corrêa [1].

Nowadays, the behavior of structural masonry at room temperature is relatively well known as there is a large body of research and a consolidated set of codes for design and construction control. However, regarding its behavior at elevated temperatures, there is still a gap in the literature concerning a clear understanding of masonry wall performance in fire situations, as discussed in Russo and Sciarretta [2].

Among the main codes, Eurocode 6 [3], as well as the American and the Australian codes ([4] and [5]), are worth mentioning, which provide methodologies for the design of structural concrete masonry in fire situations. Their design procedures include performance requirements for determining fire resistance of masonry walls, which are based on three criteria called $R$ (mechanical resistance), $E$ (integrity) and $I$ (thermal insulation). According to Eurocode 6, these criteria are assumed to be met in the following conditions:

- Criterion $R$ - when the loadbearing function is maintained throughout the required time of fire exposure;

- Criterion $I$ - when the mean temperature of the unexposed face does not rise by more than $140{ }^{\circ} \mathrm{C}$, and the maximum temperature rise at any point of that surface does not exceed $180{ }^{\circ} \mathrm{C}$;

- Criterion $E$ - when the passage of flames and hot gases through the member is prevented.

For the standard fire exposure, members shall comply with criteria according to their function in the building, as follows: Criterion $R$, for loadbearing function only (non-separating walls); Criteria $E I$, for separating function only (non-loadbearing walls); and Criteria $R E I$, for both separating and loadbearing functions.

A small number of experimental and theoretical studies aimed at evaluating the performance of masonry walls in relation to these criteria is available in the literature. Nahhas et al. [6] present experimental results of a masonry wall constructed by assembling concrete hollow blocks with three partitions and two vertical cells throughout the wall's thickness, which took more than 120 minutes to reach $200{ }^{\circ} \mathrm{C}$ on the unexposed face once subjected to the ISO 834 Standard Fire [7]. On the other hand, blocks with only one cell in the wall thickness direction tend to present a much lower performance with respect to the thermal insulation criterion, as observed in Lopes et al. [8], whose tests resulted in values between 67 and 80 minutes of fire resistance.

Based on experimental investigation, Harmathy and Allen [9] observed that a $25 \mathrm{~mm}$ thick air layer inside a concrete wall can improve its thermal insulation by up to $10 \%$ compared to solid walls with the same volume. However, as heat transfer through an air gap is practically independent of its thickness, there is no major insulation gain increasing this layer. In addition, the authors conclude that increasing the shells' thickness of hollow blocks is more efficient for the thermal insulation of masonry than increasing their webs.

Regarding the mechanical resistance, Russo and Sciarretta [2] point out that real events often demonstrate that masonry walls and structures can excellently withstand the action of fire and high temperatures. However, the wide variety of geometries and materials commonly used in blocks and joints, as well as the different possible boundary conditions, have motivated various studies to have a clearer understanding about the behavior of masonry elements in fire, such as [10]-[17].

Over the last three decades, structural masonry has been consolidated as an important part of the construction market in Brazil due to its advantages compared to reinforced concrete and steel structures, mainly because of the reduction in construction costs. Hollow concrete blocks and cement-lime based mortar joints have been widely used in structural masonry elements in both low and tall buildings, where $14 \mathrm{~cm}$ thick walls are commonly used in structural design. However, Brazilian standards do not currently provide procedures for structural masonry design at high temperatures, which represents a potential risk to the safety of masonry buildings in fire situations. In addition, few studies have been carried out in the specific field of post-fire safety of masonry structures, as pointed out in Russo and Sciarretta [2].

Thus, this paper aims to analyze aspects related to concrete hollow-blocks structural masonry, which have been underexplored in the literature, using experimental tests. Examples include performance differences between 
representative masonry elements (blocks, prisms and small walls) at elevated temperatures, the influence of the initial strength of blocks on the masonry behavior in fire situations, the fire exposure on one or both faces of walls and the residual strength of these elements after the action of fire.

\section{MATERIALS AND EXPERIMENTAL PROGRAM}

In order to evaluate the residual strength and thermal behavior of masonry, the experimental program was carried out at the Structures Laboratory at the São Carlos School of Engineering (LE/EESC/USP). It is divided into the three following stages:

1) Characterization tests at room temperature;

2) Thermal test (at elevated temperatures);

3) Post-fire compression tests.

In each of these steps, blocks, prisms and five-row small walls were tested (Figure 1), as well as mortar specimens. Hollow concrete blocks with a width equal to $14 \mathrm{~cm}$ (wall thickness) and two different nominal compression strengths equal to 4.0 MPa and 10.0 MPa were considered (nominal strengths related to the gross cross-section, which correspond to a net strength of about 7.7 MPa and 19.2 MPa, respectively). The blocks and half-blocks were manufactured by a Brazilian company specialized in precast concrete elements for civil construction (Tatu Pré-Moldados Ltda), and were produced from high-early-strength Portland cement, water, crushed diabase coarse aggregate of maximum size 12.5 $\mathrm{mm}$ and natural quartz sand as fine aggregate (siliceous aggregates). A company specialized in civil construction was hired to build the specimens at the laboratory (LE/EESC/USP), therefore all masonry elements included in this experimental investigation were built by an experienced mason.

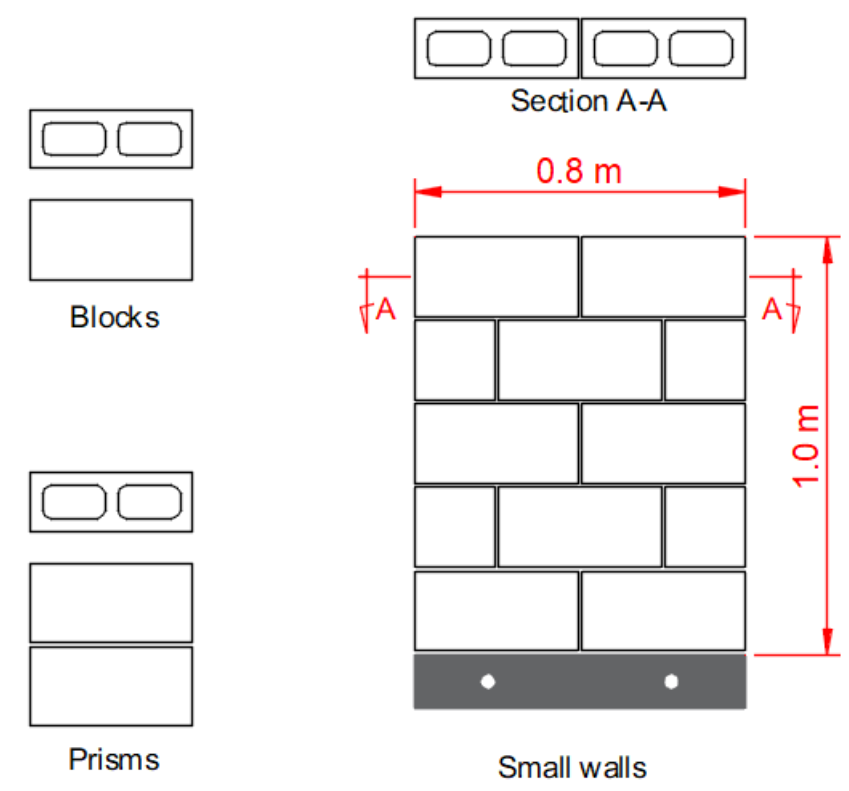

Figure 1. Test specimens: blocks, prisms and small walls.

The mortar was made of Portland cement, lime and river sand produced in a concrete mixer at the laboratory, following 1:0.5:4.5 as volume and water/cement ratio equal to 1.23 (average consistence index equal to 248.2, which was obtained according to Associação Brasileira de Normas Técnicas [18]). Prisms and small walls were assembled with full bedding with $1 \mathrm{~cm}$ thick joints. In order to ensure the accuracy of the joints' thickness, $10 \mathrm{~mm}$ diameter steel bars were used as a template between blocks while constructing the samples and were removed as soon as mortar had sufficient strength to support the blocks above. All prisms and small walls were stored in the laboratory and were submitted to air curing in a covered environment until testing. For each type of element tested, 6 blocks, 6 half-blocks, 6 prisms, 3 small walls and 6 mortar specimens were used according to the sampling defined in standards [19]-[21], as detailed in Table 1. 
Table 1. Sampling and tests.

\begin{tabular}{|c|c|c|c|c|c|}
\hline \multirow{2}{*}{\multicolumn{2}{|c|}{ Specimen }} & \multicolumn{2}{|c|}{ Room temperature } & \multirow{2}{*}{$\begin{array}{c}\text { Furnace } \\
\text { Fire }\end{array}$} & \multirow{2}{*}{$\begin{array}{c}\text { Post fire } \\
\text { Compression } \\
\end{array}$} \\
\hline & & $\begin{array}{l}\text { Physical - } \\
\text { geometric }\end{array}$ & Compression & & \\
\hline & Block & 6 & 6 & 6 & 6 \\
\hline $4 \mathrm{MPa}$ & Half-block & 6 & 6 & - & - \\
\hline \multirow[t]{4}{*}{$\left(7.7 \mathrm{MPa}^{*}\right)$} & Prism & - & 6 & 6 & 6 \\
\hline & Small wall & - & 3 & 3 & 3 \\
\hline & Trio $^{* *}$ & - & - & 3 & 3 \\
\hline & Block & 6 & 6 & 6 & 6 \\
\hline $10 \mathrm{MPa}$ & Half-block & 6 & 6 & - & - \\
\hline \multirow[t]{2}{*}{$\left(19.2 \mathrm{MPa}^{*}\right)$} & Prism & - & 6 & - & - \\
\hline & Small wall & - & 3 & 3 & 3 \\
\hline \multicolumn{2}{|c|}{ Mortar cylinders } & - & 6 & 6 & $0^{* * *}$ \\
\hline
\end{tabular}

*nominal compression strength considering the net cross-section. $* *$ group of three small walls, as presented in Item $2.2 . * * *$ no post-fire tests were carried out with the mortar specimens due to their degradation, as presented in Item 3.2.

The experiments were planned according to the laboratory schedule and the activities related to the preparation of the tests, such as transporting samples, curing, instrumentation and thermal insulation of specimens' parts with a ceramic fiber blanket. Thus, the tests using blocks, prisms and small walls were carried out at room temperature between 60 and 72 days after constructing of the specimens; mortar specimens were then tested at 91 days of age. Finally, the masonry specimens were tested at elevated temperatures 104 days after being constructed, followed by the post-fire tests seven days after fire exposure.

\subsection{Characterization tests at room temperature}

Table 2 presents the physical and geometric properties of blocks and half blocks used, obtained through tests prescribed in Associação Brasileira de Normas Técnicas [19] and [20].

Table 2. Physical and geometric properties of blocks and half blocks.

\begin{tabular}{|c|c|c|c|c|c|c|c|c|c|c|}
\hline \multirow[b]{2}{*}{ Block } & \multicolumn{3}{|c|}{ External dimensions } & \multicolumn{3}{|c|}{ Thickness } & \multicolumn{3}{|c|}{ Areas } & \multirow{2}{*}{$\begin{array}{c}\text { Absorption } \\
(\%)\end{array}$} \\
\hline & $\begin{array}{c}\mathrm{L} \\
(\mathrm{mm})\end{array}$ & $\begin{array}{c}\text { B } \\
(\mathbf{m m})\end{array}$ & $\begin{array}{c}\mathrm{H} \\
(\mathrm{mm})\end{array}$ & $\begin{array}{c}e_{\mathrm{L}} \\
(\mathbf{m m})\end{array}$ & $\begin{array}{c}e_{\mathrm{T}} \\
(\mathrm{mm})\end{array}$ & $\begin{array}{c}e_{\mathrm{S}} \\
(\mathrm{mm})\end{array}$ & $\begin{array}{l}\text { Gross } \\
\left(\mathbf{m m}^{2}\right)\end{array}$ & $\begin{array}{c}\text { Net } \\
\left(\mathrm{mm}^{2}\right)\end{array}$ & $\begin{array}{c}\mathbf{A}_{\mathrm{Gross}} / \mathbf{A}_{\mathrm{Net}} \\
(\%)\end{array}$ & \\
\hline $4 \mathrm{MPa}$ block & 390 & 139 & 190 & 25.6 & 25.5 & 26.5 & 54337 & 28221 & 52 & 6.6 \\
\hline $10 \mathrm{MPa}$ block & 390 & 139 & 190 & 25.6 & 25.6 & 26.4 & 54359 & 28356 & 52 & 4.4 \\
\hline $4 \mathrm{MPa}$ half-block & 191 & 138 & 188 & 25.3 & 25.3 & - & 26338 & 14708 & 56 & 6.0 \\
\hline $10 \mathrm{MPa}$ half-block & 191 & 138 & 191 & 25.5 & 25.5 & - & 26430 & 14913 & 56 & 5.0 \\
\hline
\end{tabular}

In order to evaluate the residual compressive strength (post-fire) of the masonry, compression tests were initially performed at room temperature (elements presented in Figure 1), whose results are taken as a reference in subsequent analyses at elevated temperatures.

For testing blocks, half blocks and prisms, a servo-controlled Instron 300 HVL machine was used, with a maximum load capacity of $1500 \mathrm{kN}$ (Figure 2a). After initial accommodation cycles, loading was progressively applied at a rate of $0.02 \mathrm{~mm} / \mathrm{s}$ (displacement control) until specimen rupture was achieved. In order to reduce stress concentration and the 
influence of the loading platens on the results, the compression tests were carried out with $50 \mathrm{~mm}$ thick platens and 20 $\mathrm{mm}$ mineral fiber capping boards at the top and bottom of the specimens, as also used in Oliveira [22] and Izquierdo [23].

In the case of small walls, an Instron 8506 servo-controlled device was used (Figure 2b), which has a load capacity of up to $2500 \mathrm{kN}$. Loading was also applied with displacement control at a rate of $0.01 \mathrm{~mm} / \mathrm{s}$. In order to obtain the stress-strain curve and the modulus of elasticity of the assembly, four LVDT displacement transducers were fixed by pairs on both faces of the small walls, as illustrated in Figure 2c.

Cylindrical specimens of $50 \mathrm{~mm}$ diameter and $100 \mathrm{~mm}$ height were cast to determine the compression and tensile strength of the mortar. The samples were removed from the molds after 24 hours and then transferred to air curing in the same place where the blocks, prisms and small walls were stored (covered environment and temperature between 20 and $30{ }^{\circ} \mathrm{C}$ ) to avoid the influence of humidity on the results. Instron $300 \mathrm{HVL}$ was also used for the compression tests considering a loading rate of $0.01 \mathrm{~mm} / \mathrm{s}$ (Figure 3a). Two clip-gages were fixed on the specimens in order to determine the modulus of elasticity, which were calculated according to American Society for Testing and Materials [24], i.e. the secant modulus referring to $5 \%$ and $33 \%$ of the peak stress. The average results of compression strength and modulus of elasticity were, respectively, $4.90 \mathrm{MPa}$ (coefficient of variation $\mathrm{CV}=8.15 \%)$ and $10.99 \mathrm{GPa}(\mathrm{CV}=$ $16,33 \%$ ), with an average peak strain equal to $1.10 \%$.

An ELE Autotest 2000 machine was used to determine the mortar tension strength by means of diametrical compression tests on 6 cylindrical specimens (Figure 3b), which were carried out as prescribed in Associação Brasileira de Normas Técnicas [25]. The average result was equal to $0.63 \mathrm{MPa}$, with a $\mathrm{CV}=17.51 \%$.

\subsection{Experimental program at elevated temperatures}

The elements shown in Figure 1 were analyzed at elevated temperatures using a gas-fueled furnace, as shown in Figure 4, which has internal dimensions of $4 \mathrm{~m} \times 3 \mathrm{~m} \times 1.5 \mathrm{~m}$ and can simulate the ISO 834 Standard Fire curve [7]. This heating device has eight burners that work under the control of a control center to reproduce the temperature-time curve specified for the test. Temperature evolution is controlled by nine thermocouples (named TP1 to TP9), which are evenly distributed in the furnace's internal space.

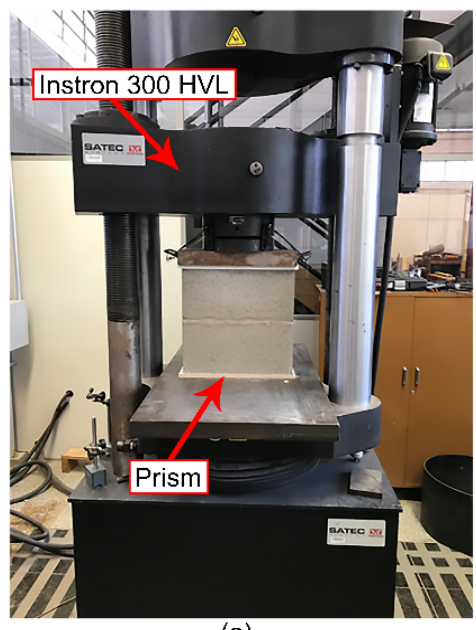

(a)

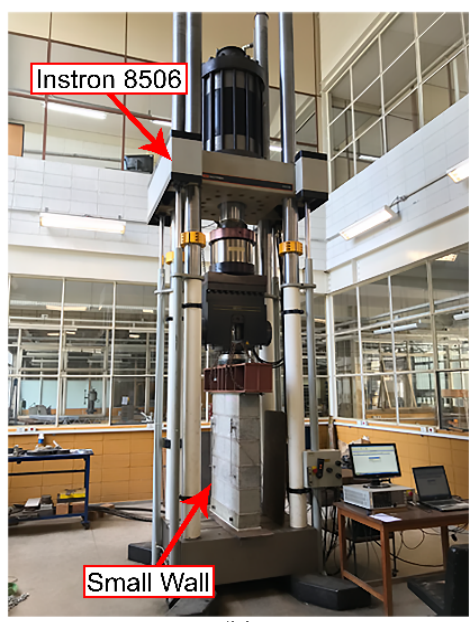

(b)

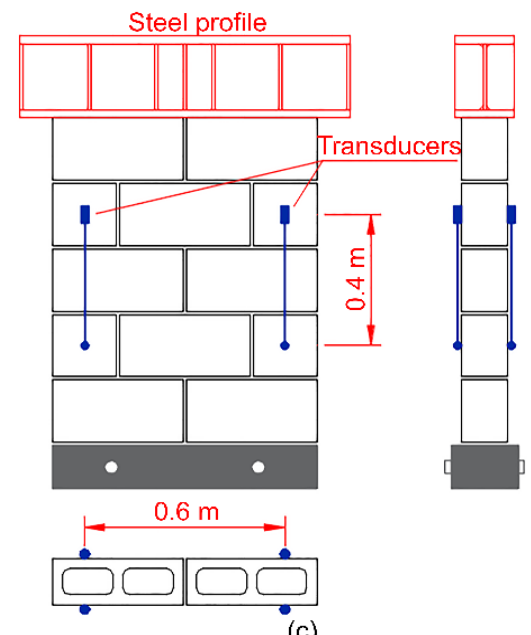

(c)

Figure 2. Compression tests of blocks, prisms and small walls at room temperature. 


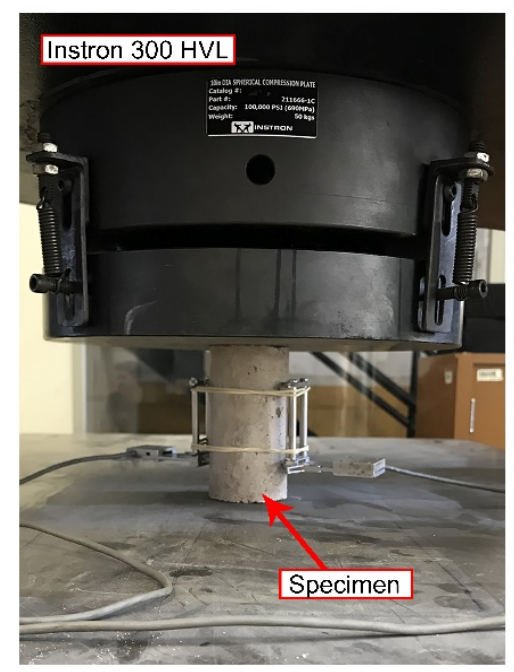

(a)

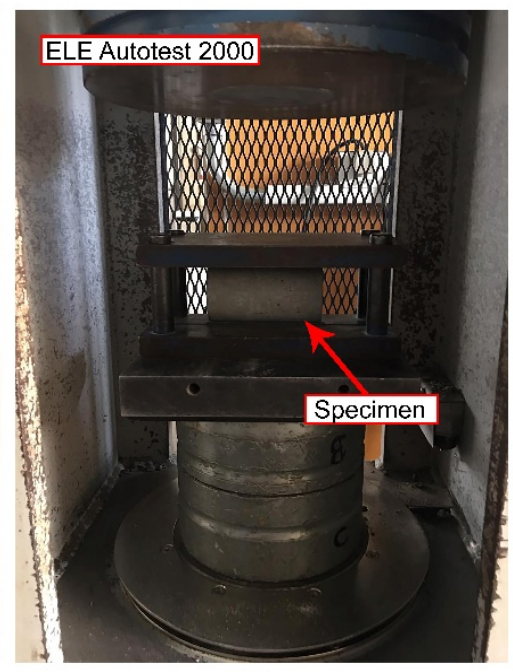

(b)

Figure 3. Bedding mortar: (a) compression and (b) tensile tests.

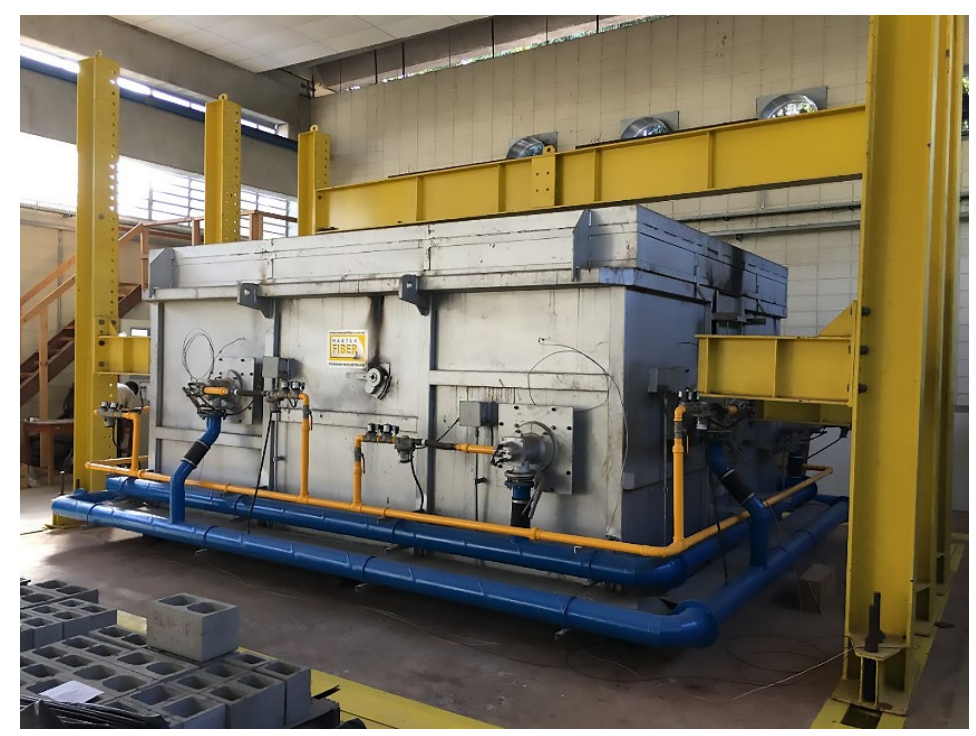

Figure 4. External view of the furnace used in the test.

Figure 5 shows the distribution of specimens inside the furnace, which were positioned far enough away from the burners so that there was no direct contact with flames. The experiment was performed with unloaded elements inside the furnace, i.e., blocks, prisms and small walls were initially exposed only to the action of fire. In addition, the separating function of masonry was investigated by the trio of small walls shown in Figure 5, which were exposed to fire on only one of their faces.

A $50 \mathrm{~mm}$ thick and $128 \mathrm{~kg} / \mathrm{m}^{3}$ density ceramic fiber blanket was used on the top and bottom sections of all specimens to ensure the thermal insulation of the interior of blocks in the furnace. In addition, the same type of blanket was used to insulate the internal space of the trio of small walls and their vertical interfaces, as can be seen in Figure 5 .

The instrumentation of specimens was made using type $\mathrm{K}$ thermocouples, which were fixed at various points along the mid-height cross section of the elements: firstly, small holes were drilled in the blocks using a 4.0 mm diameter drill and then thermocouples were fixed with cement paste at the desired depths to obtain temperature measurements. Cement paste was chosen to fix the thermocouples due to the similarity between the thermal properties of both materials (concrete and cement paste), as well as its easy handling. In order to assess the reliability of measurements, two 
specimens of each type were instrumented (i.e, four blocks, four small walls, two small walls of the trio and two prisms), totaling 47 thermocouples. Temperature measurements were logged at each second of fire exposure during the test.

The moisture content of blocks was also determined before the test. The mass of six blocks were measured in moist condition and after drying for 24 hours in a chamber at $(110 \pm 5)^{\circ} \mathrm{C}$; the blocks were inserted into the chamber for another two hours to assess further changes in mass. Thus, the moisture content was then determined from the difference between the moist and dry mass, resulting in $1.2 \%$ for 4 MPa blocks and $1.7 \%$ for $10 \mathrm{MPa}$ blocks.
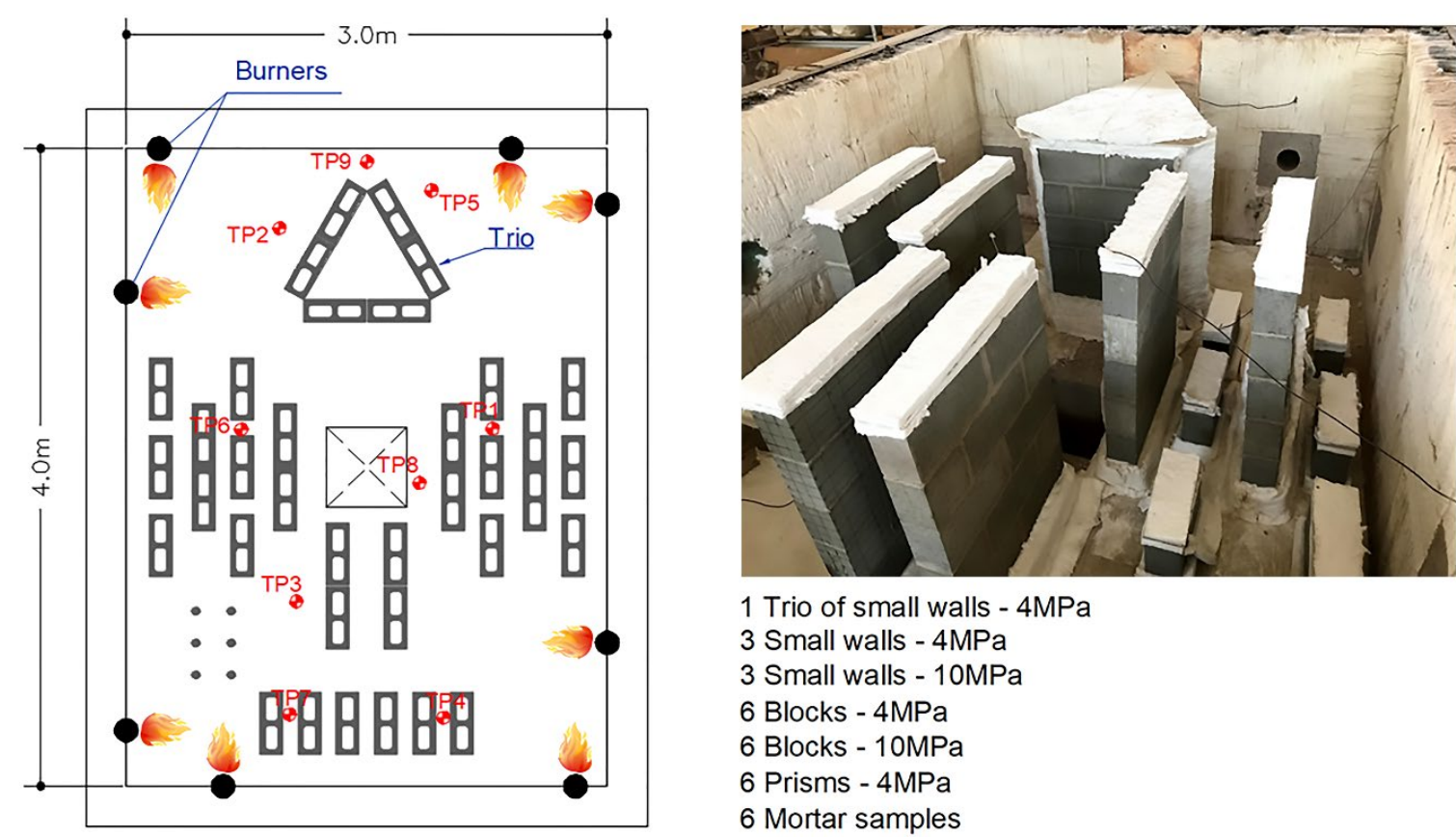

1 Trio of small walls $-4 \mathrm{MPa}$

3 Small walls - $4 \mathrm{MPa}$

3 Small walls - $10 \mathrm{MPa}$

6 Blocks - $4 \mathrm{MPa}$

6 Blocks - 10MPa

6 Prisms - 4MPa

6 Mortar samples

Figure 5. Test at elevated temperature: distribution of the specimens inside the furnace.

\subsection{Post-fire compression tests}

After exposure to fire, specimens were slowly cooled while still in the furnace, taking approximately 20 hours to cool completely. The residual strength of elements was then obtained by compression tests similar to those described in Item 2.1 and were performed seven days after the furnace test.

\section{RESULTS AND DISCUSSION}

\subsection{Temperature level values}

Specimens were submitted to the ISO 834 Standard Fire [7] for 70 minutes, where the maximum average temperature reached inside the furnace was $972{ }^{\circ} \mathrm{C}$. Figure 6 shows the results of small walls exposed to fire on all their external faces, in which masonry does not act as a separating element. The measurements indicated in the captions refer to the distance from the analyzed point to the nearest fire exposed face, both for walls built with 4 MPa blocks (continuous lines) and for $10 \mathrm{MPa}$ blocks (dashed lines). These curves correspond to the average results of two specimens for each point investigated as there were no large differences in the results of the thermocouples at any point. In addition, "Mort. $13 \mathrm{~mm}$ " represents the temperature evolution at $13 \mathrm{~mm}$ depth in the mortar joints; this curve corresponds to the average results of four thermocouples located at the mid-height horizontal joint of four different small walls. 

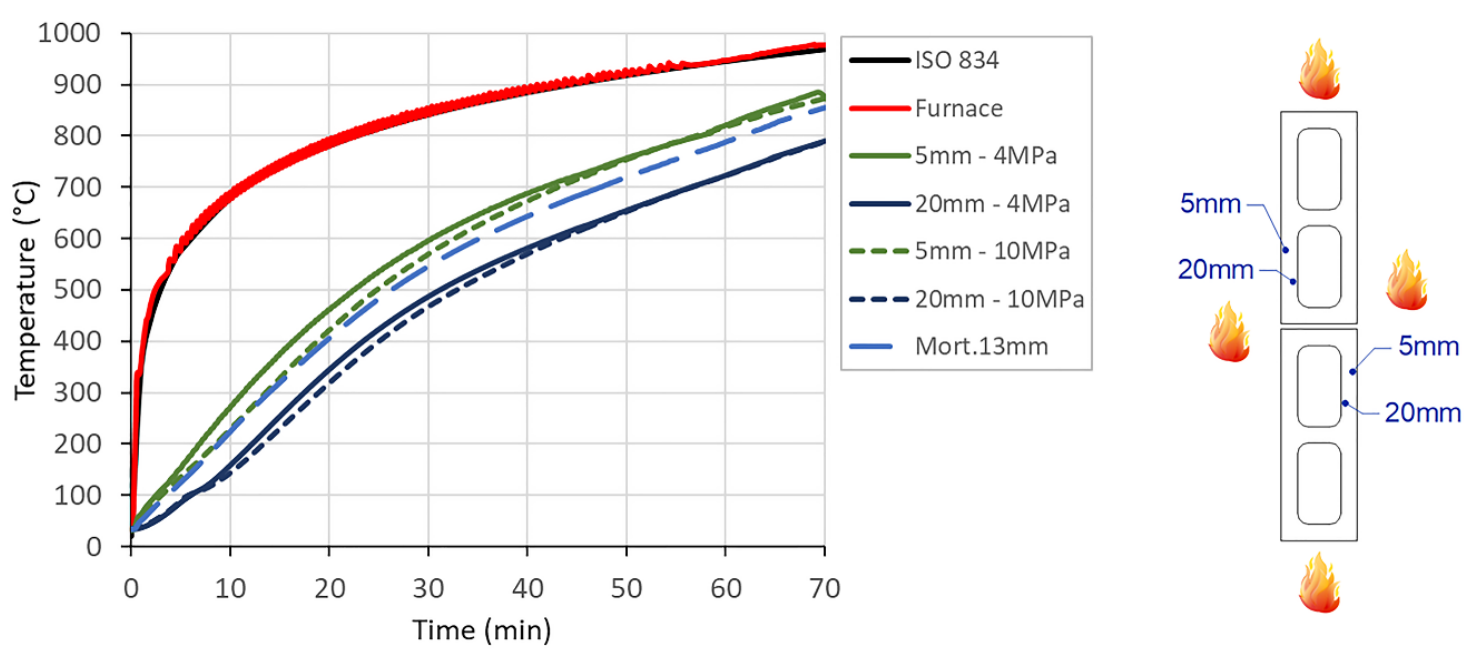

Figure 6. Small walls with fire acting on all their faces.

As expected, an important difference in slope can be noted when comparing the beginning of the $5 \mathrm{~mm}$ and $20 \mathrm{~mm}$ depth curves. This delay in the temperature rise in deeper sections within concrete members depends on the thermal properties of the material and increases considerably as a function of the moisture content of the concrete, as mentioned in Buchanan and Abu [26].

Although the temperature evolution in $10 \mathrm{MPa}$ block walls was lower than in $4 \mathrm{MPa}$ block walls throughout the test, there was a close proximity between the results, as can be seen when comparing the dashed curves with the continuous ones at each investigated point. Thus, the results indicate a small variation of thermal properties as a function of the block strength or, in other words, the difference between the thermal properties of both concretes (4 MPa and 10 MPa blocks) does not strongly influence the temperature rise through the masonry cross section. In addition, the curve for the mortar joint ("Mort.13mm") shows a similar trend when compared to those of blocks. Therefore, although the materials of the blocks and joints studied here may present different values of thermal and physical properties (specific heat, thermal conductivity and density), when considered simultaneously, these properties led to similar temperature rises in the masonry elements tested, which means that their materials have similar thermal diffusivities.

As shown in Table 2, the analyzed blocks have shells with an average thickness of $25 \mathrm{~mm}$. In this case, it was observed that practically the entire wall thickness was submitted to temperatures above $500^{\circ} \mathrm{C}$ in less than 40 minutes when exposed to the standard fire on both faces, a temperature at which concrete already has a large reduction in its residual strength (about 40\%, according to European Standards [27]). At 70 minutes, the maximum temperatures reached at points of $5 \mathrm{~mm}$ and $20 \mathrm{~mm}$ deep were around $875^{\circ} \mathrm{C}$ and $800^{\circ} \mathrm{C}$, respectively, which is critical for concrete in terms of loss of strength: between $85 \%$ and $92 \%$ considering siliceous aggregate concrete [27].

Aiming to assess any possible differences in the temperature evolution in individual blocks and prisms when compared to walls (which would result in different percentage losses in terms of residual strength between these elements), four blocks and two prisms were also instrumented with thermocouples. Figure 7 shows the average temperature-time curves obtained at the indicated instrumentation points, where continuous lines refer to blocks with nominal strength of $4 \mathrm{MPa}$ and dashed lines to $10 \mathrm{MPa}$ blocks.

As in the small walls, $10 \mathrm{MPa}$ blocks presented lower temperatures than $4 \mathrm{MPa}$ blocks, but with few marked differences. The same pattern can be observed in mortar joints ("Mort.13mm"), whose temperature-time curve shows a similar trend when compared to the same measurement point in the block (point at $13 \mathrm{~mm}$ deep). Therefore, the results indicate that, depending on the mortar properties, the use of simpler specimens (such as blocks and prisms) may lead to satisfactory results when the focus is the representation of heat transfer along the thickness of masonry walls.

When analyzing curves for webs and cores, it is apparent that the preferred heat flow path is through blocks' cells rather than solid parts, since the temperature increase in the cells is greater than in their webs (at least up to 43 minutes, when thermocouples fixed at this those points have measurement problems), as can be seen by comparing the "Void" and "Web" curves in Figure 7. This finding is consistent with observations presented in Harmathy and Allen [9], which concluded that the presence of cavities is more beneficial for the thermal insulation of masonry the higher the thermal conductivity of concrete. 

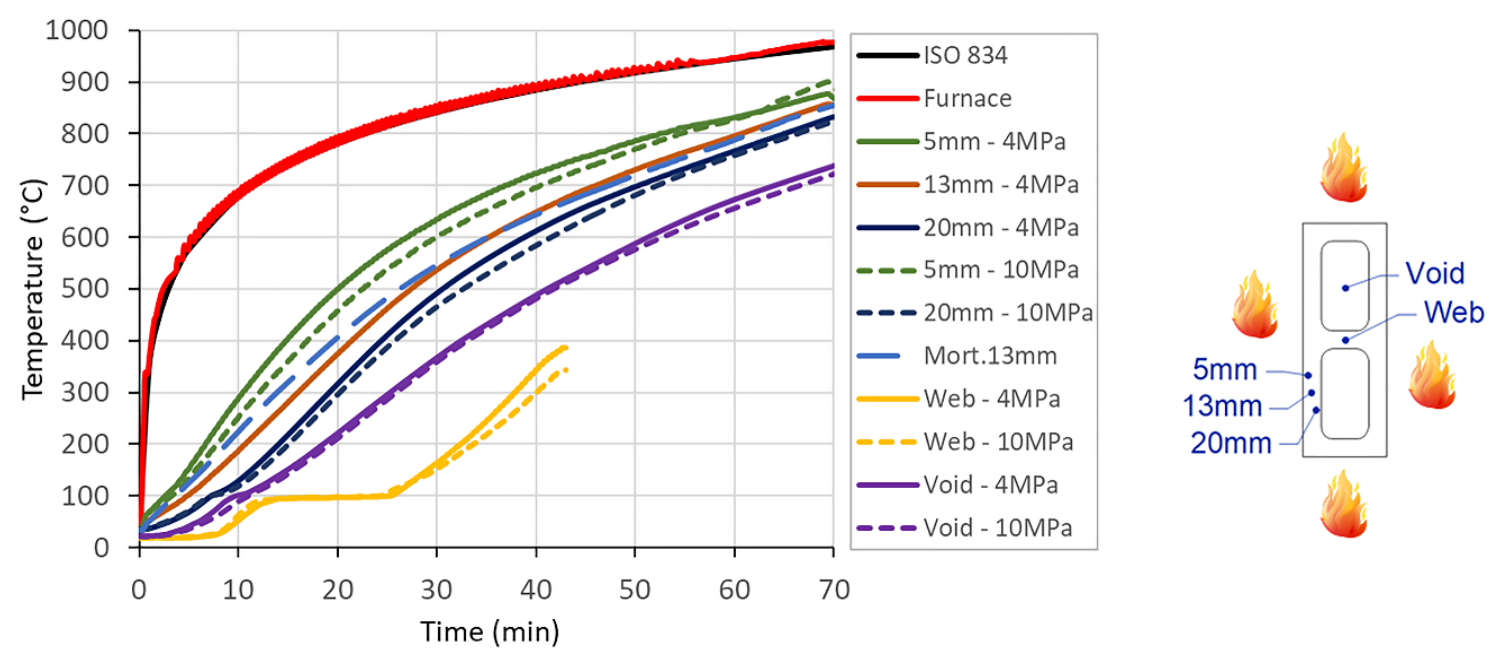

Figure 7. Blocks with fire acting on all their faces.

Figure 8 presents the average results of temperature rise at some points along the cross section related to the trio of small walls (fire acting on only one face), where the indicated measurements refer to the distance from the analyzed point to the exposed face and "Internal" refers to the air temperature measurements within the trio of small walls. Due to the presence of hollow cores in blocks, a large temperature difference can be observed between the exposed and unexposed masonry faces, with a maximum difference of around $680^{\circ} \mathrm{C}$ at the end of the test.
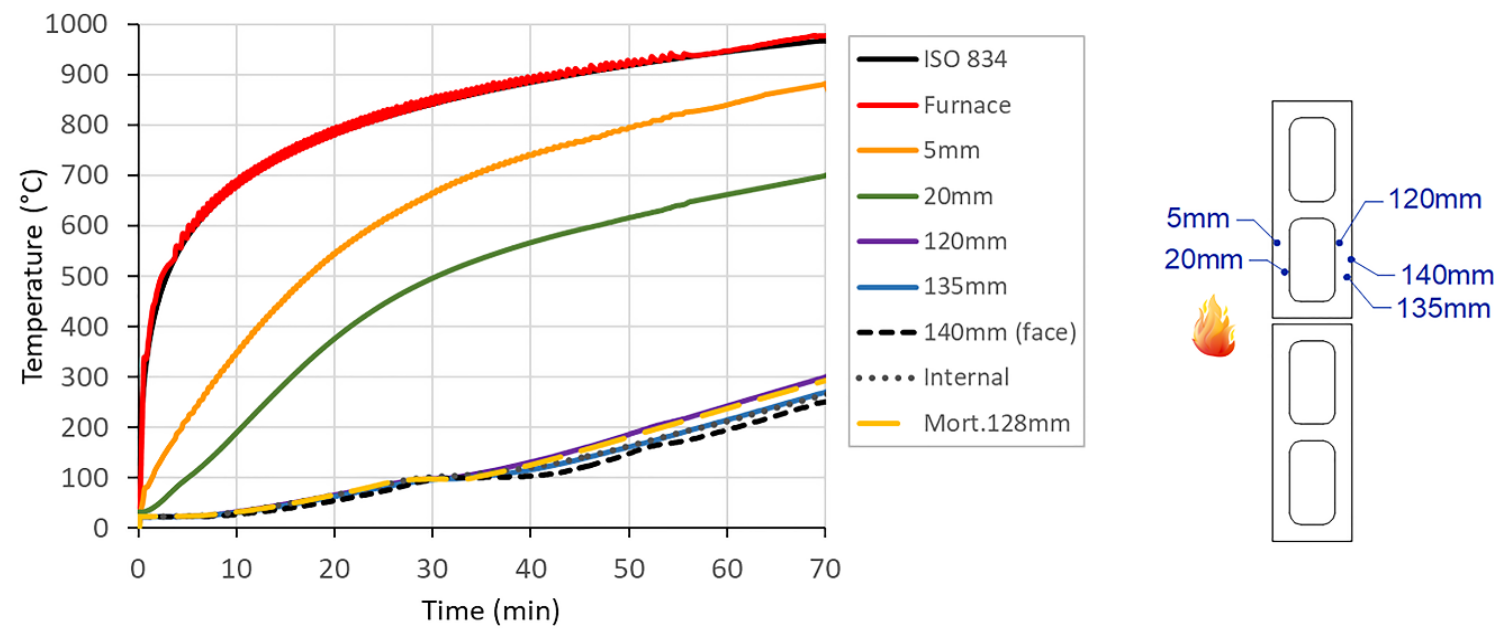

Figure 8. Small walls with fire acting on only one of its faces.

In this context, the thermal insulation criterion was evaluated based on the thermocouple measurements fixed on the unexposed face (point at $140 \mathrm{~mm}$ ), resulting in a fire resistance time of approximately 62 minutes (the time when the maximum temperature on the unexposed surface reached $180^{\circ} \mathrm{C}$ plus the initial test temperature). Considering, for example, requirements of Associação Brasileira de Normas Técnicas [28] and British Standards Institution [29] for minimum periods of fire resistance, this time would only be suitable for residential buildings with a maximum height of $23 \mathrm{~m}$ and $18 \mathrm{~m}$, respectively.

As also found in Nahhas et al. [6] and Lopes et al. [8], a plateau was observed at $100{ }^{\circ} \mathrm{C}$ in some of the curves, especially at points furthest from the exposed face, also observed in Figure 7, where the same temperature remains constant for a few minutes. This phenomenon is a result of moisture content in concrete, which tends to absorb a large 
amount of energy due to free water vaporization and, consequently, sharply increases the specific heat of the material at this temperature level. Therefore, a delay is observed in temperature evolution on the unexposed face (see the "140mm (face)" curve in Figure 8), contributing to the increase in the fire resistance time according to the thermal insulation criterion.

Considering that the blocks' shells are about $25 \mathrm{~mm}$ thick (see Table 2), it can be inferred that the entire thickness of the exposed shells reached temperatures above $500^{\circ} \mathrm{C}$ during the 70 minutes of fire exposure based on the measurements of the thermocouples located at $20 \mathrm{~mm}$ deep. This result directly impacted the residual strength of the walls (as will be seen next), although the temperature on the unexposed side remained below $250^{\circ} \mathrm{C}$ during heating.

It is noteworthy that the evolution of the temperature inside the furnace precisely reproduced the Standard Fire, as can be seen in Figures 5 to 7, where the average temperature curve of the furnace is similar to the ISO 834 curve. The efficiency of the ceramic fiber blanket can be noted in Figure 8, where the temperatures reached inside the trio of small walls ("Internal curve") remained much lower than the furnace temperature during the test, indicating a good thermal insulation effect provided by the ceramic blanket. After turning off the furnace, the trio of walls continued to heat up, as the furnace temperature remains higher when compared to the temperature inside the trio for a while, reaching a maximum temperature of $449^{\circ} \mathrm{C}$ on the unexposed face.

\subsection{Degradation of materials}

The obtained results signalize that masonry tends to experience different kinds of damage according to concrete strength, as shown in Figure 9. Due to the thermal expansion, higher compressive strength blocks present substantial cracks during heating, although their material remained in an adequate apparent condition at the end of the test. On the other hand, less resistant blocks showed only discrete superficial cracks, but showing evidence of considerable material degradation, given that $4 \mathrm{MPa}$ blocks could be easily broken when handled after fire exposure.

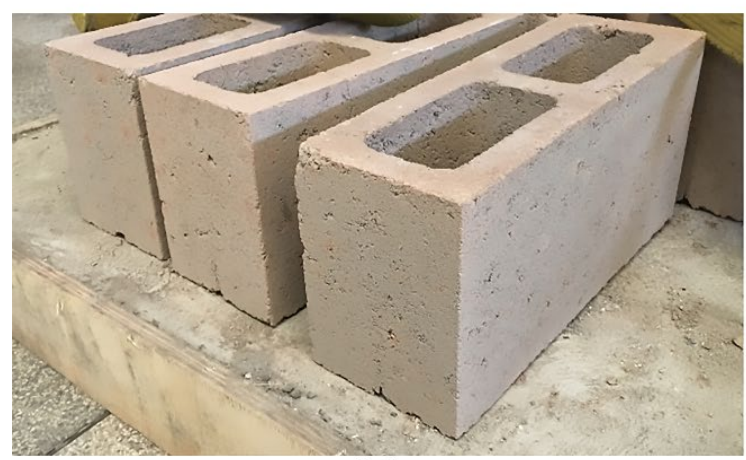

(a)

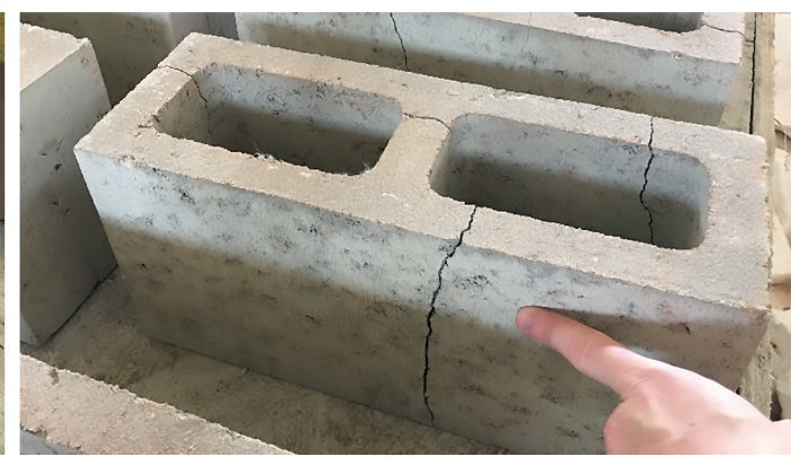

(b)

Figure 9. Blocks with nominal strength of (a) $4 \mathrm{MPa}$ and (b) $10 \mathrm{MPa}$ after heating.

An analogue situation was also observed on prisms and small walls, emphasizing the tendency of crack formation on the lateral face along the height of the walls (Figure 10a). In addition, a crack pattern was observed on both front faces of the elements, where slightly curved vertical cracks close to the blocks' webs can be noted (Figure 10a). In the small walls, the observed amount of cracks was much lower than in the individual blocks, especially in lower rows, suggesting that compressive loading (in this case, the self-weight of upper on lower blocks) and the confinement effect of joints and adjacent blocks tend to reduce the occurrence of cracks due to thermal expansion, hence also contributing to the performance of walls with respect to the integrity criterion.

Regarding walls with fire heating up on only one face (in this case, the trio), the temperature gradient along the section resulted in the curving of walls, with an average top displacement of around $2.8 \mathrm{~cm}$ in relation to the base (Figure 10b). This measurement was performed after cooling the specimens, given that transducers do not resist the high temperatures inside the furnace during the experiment. Despite this thermal bowing, no cracks were observed at the block-joint interfaces, possibly because of the absence of loads and restraints to thermal expansion on the walls, which tend to increase deflections due to second-order effects. No spalling was observed in any of the samples. 


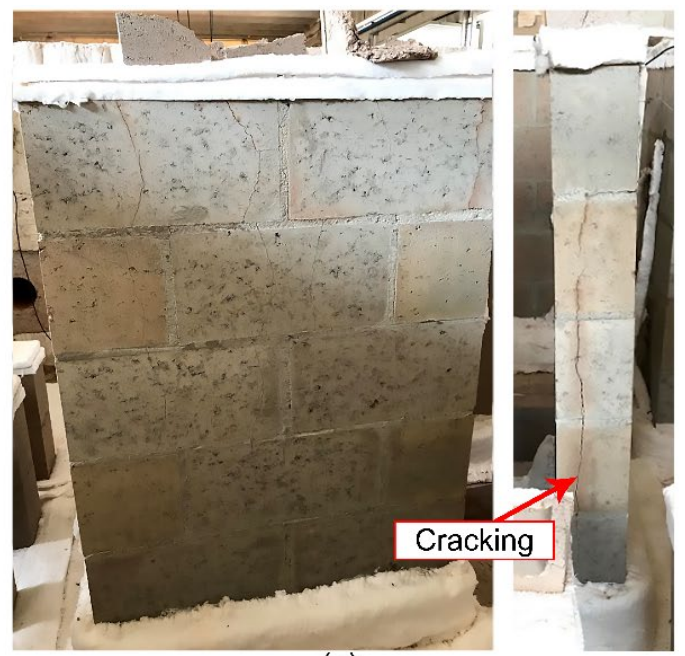

(a)

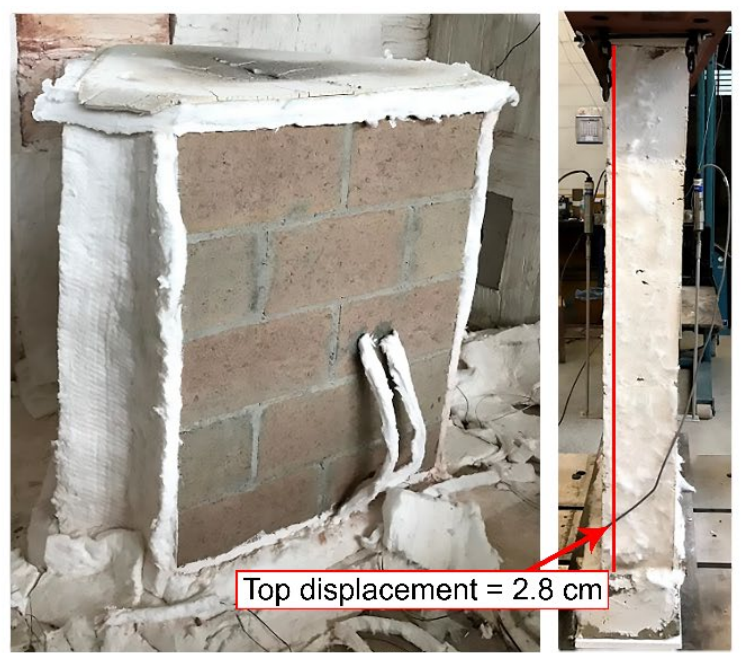

(b)

Figure 10. Small walls after the test: fire on (a) all faces and (b) one face (trio).

Figure 11 shows the mortar specimens immediately after cooling and seven days after the test. For the first situation, the material only had a few discrete and apparently superficial cracks (Figure 11a). One week later, mortar samples presented considerable degradation, showing evidence of a large number of deep cracks and, also, with no residual strength (Figure 11b). This is due to changes that occurred in the lime used in mortar at high temperatures, which turns calcium hydroxide $\left(\mathrm{Ca}(\mathrm{OH})_{2}\right)$ into calcium oxide $(\mathrm{CaO})$ between $400-500{ }^{\circ} \mathrm{C}$; upon cooling, this compound reacts with atmospheric carbon dioxide $\left(\mathrm{CO}_{2}\right)$ and gives rise to calcium carbonate $\left(\mathrm{CaCO}_{3}\right)$, resulting in an expansion of the material [30], [31].

This cracking behavior did not happen in mortar joints of small walls, even though it was the same material. It appears that the confinement between blocks ultimately results in a beneficial effect on the mortar joints and restricts the crack formation (see Figure 10), contrary to what happens to cylindrical specimens shown in Figure 11b. Therefore, further investigations are needed to evaluate the performance of cement and lime-based mortars in bedding joints of masonry structures in fire situations, especially in cases of load-bearing walls.

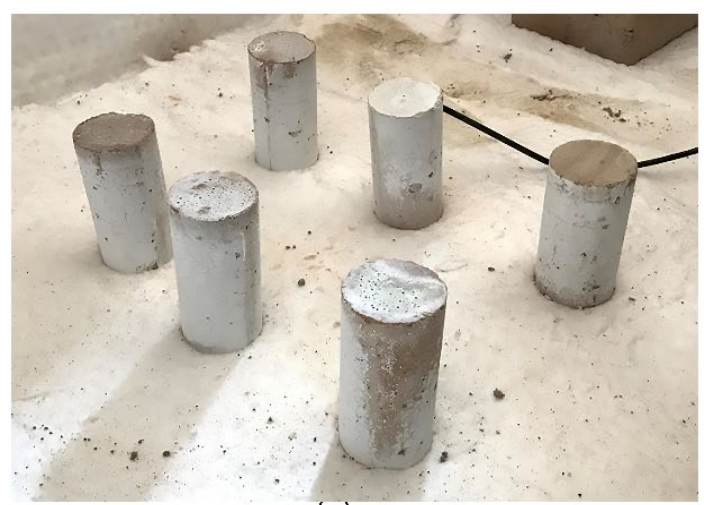

(a)

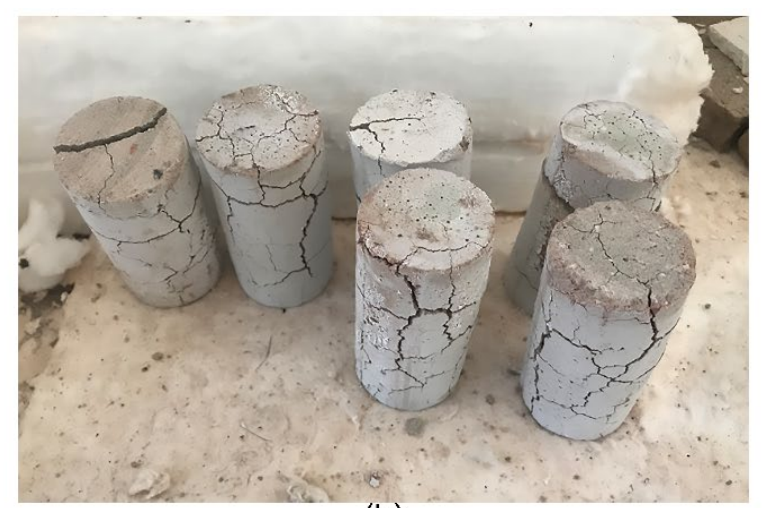

(b)

Figure 11. Bedding mortar specimens (a) one day after the test and (b) seven days after the test.

\subsection{Residual Mechanical Properties}

Figure 12 presents the results of the compression tests performed before and after the exposure to standard fire. Values refer to the characteristic and average strengths in relation to the gross section area $\left(f_{\mathrm{k}}\right.$ and $\left.f_{\mathrm{m}},\right)$ and the average strength in the net section area $\left(f_{\mathrm{m}, \mathrm{liq}}\right)$, which are calculated according to the requirements of Brazilian standards [19] 
and [21]. Table 3 summarizes the post-fire results, highlighting the residual strength as a percentage of the average strength at room temperature.

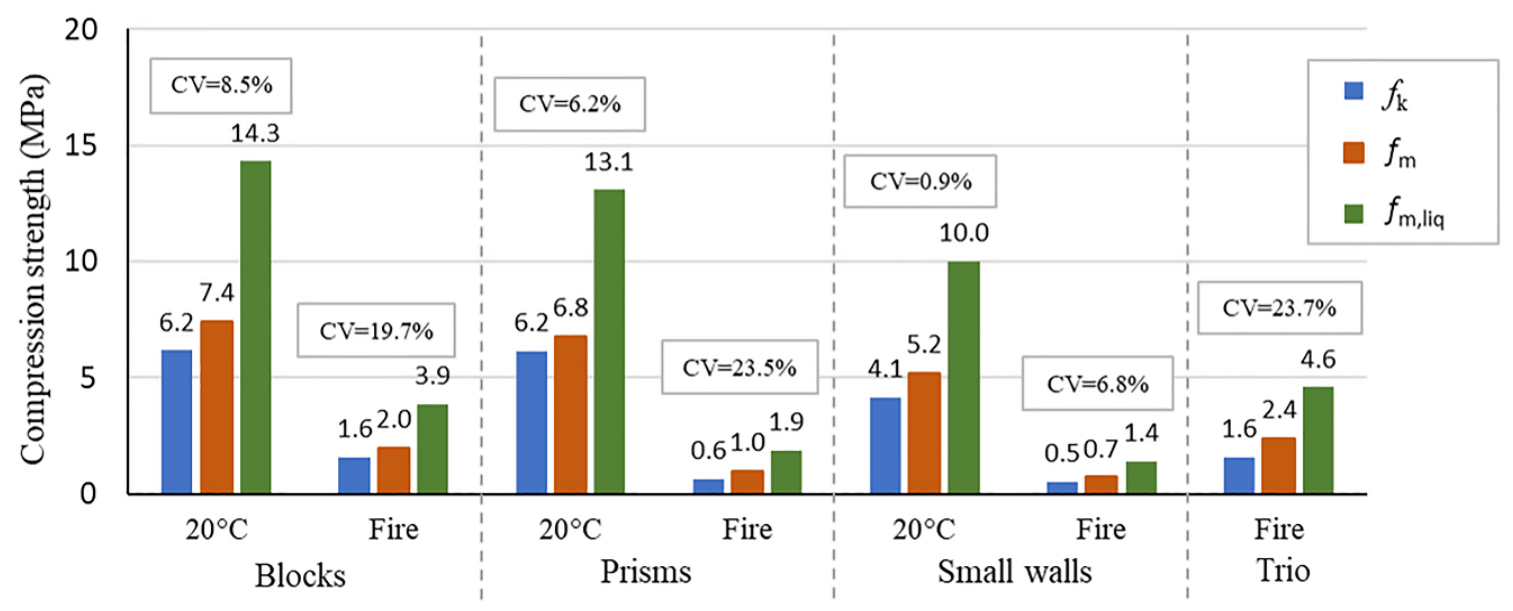

(a)

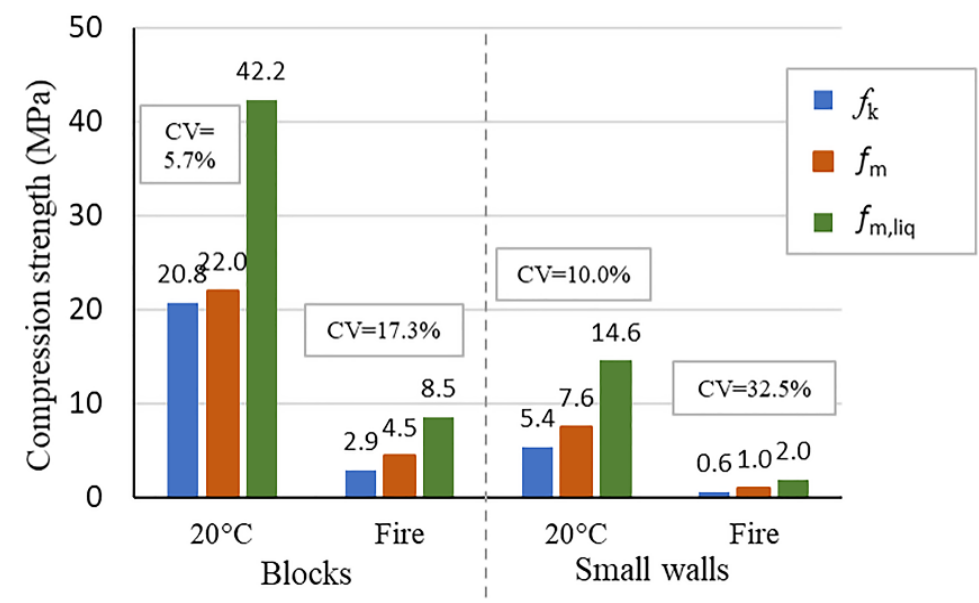

(b)

Figure 12. Compressive strength before and after fire: (a) 4 MPa blocks and (b) $10 \mathrm{MPa}$ blocks (nominal).

Table 3. Residual compression strength after 70 minutes under the ISO 834 Standard Fire.

\begin{tabular}{|c|c|c|c|c|c|c|c|c|}
\hline \multirow{2}{*}{ Blocks' nominal strength } & \multicolumn{2}{|c|}{ Blocks } & \multicolumn{2}{|c|}{ Prisms } & \multicolumn{2}{|c|}{ Small walls } & \multicolumn{2}{|c|}{ Trio } \\
\hline & $F_{\text {fire }}(\mathbf{k N})$ & $\mathbf{F}_{\text {fire }} / \mathbf{F}_{\text {room }}$ & $F_{\text {fire }}(\mathbf{k N})$ & $\mathbf{F}_{\text {fire }} / \mathbf{F}_{\text {room }}$ & $F_{\text {fire }}(\mathbf{k N})$ & $F_{\text {fire }} / F_{\text {room }}$ & $F_{\text {fire }}(\mathbf{k N})$ & $\mathbf{F}_{\text {fire }} / \mathbf{F}_{\text {room }}$ \\
\hline $4 \mathrm{MPa}$ & 108.7 & $27 \%$ & 52.8 & $14 \%$ & 79.3 & $14 \%$ & 259.0 & $46 \%$ \\
\hline $10 \mathrm{MPa}$ & 242.3 & $20 \%$ & - & - & 111.5 & $13 \%$ & - & - \\
\hline
\end{tabular}

$\mathrm{F}_{\text {fire }}-$ average compression strength after cooling (residual strength). $\mathrm{F}_{\text {room }}-$ average compression strength at room temperature (before fire exposure).

Room-temperature tests indicate that the characteristic strength of blocks is much higher than the nominal strengths specified by the manufacturer: $6.2 \mathrm{MPa}$ and $20.8 \mathrm{MPa}$ instead of $4 \mathrm{MPa}$ and $10 \mathrm{MPa}$. In addition to the results shown in Figure 12, half-blocks were also tested at room temperature according to the sampling presented in Table 1, resulting 
in average compression strengths in the gross section area equal to $10.7 \mathrm{MPa}$ and $18.4 \mathrm{MPa}$ (characteristic strength equal to $9.4 \mathrm{MPa}$ and $14.1 \mathrm{MPa}$ ), with a coefficient of variation of 8.6 and 10.8 , respectively.

After the furnace test, a large loss of masonry strength was observed, especially for elements exposed to fire on both faces, where the residual strength resulted in less than a quarter for most tested elements. In addition, there is a considerable increase in the coefficient of variation (CV) on individual results of specimens around the mean, which influences the characteristic strength of elements.

Higher strength blocks presented considerable percentage strength reduction when compared to lower strength blocks, probably due to the higher incidence of cracking during heating. Additionally, the results show that prisms and small walls tend to experience an expressive loss of strength when compared to the blocks, indicating an influence of the mortar joints on the residual masonry strength, as expected. In this context, it was observed that, in percentage, prisms and small walls showed the same strength as post-fire compression (around 14\%), which may be an indication that using simpler specimens (such as two-block prisms) can lead to satisfactory results in the evaluation of the residual compressive masonry strength as a whole, considering the slenderness effects separately.

The results of the trio of small walls indicate that this type of structural masonry performs much better when exposed to fire on only one face (wall acting as a separating element during fire), resulting in residual strength about three times higher than fire exposure to both faces (considering similar boundary conditions in both cases). However, it is noteworthy that the test lasted 70 minutes, and therefore elements did not reach the most critical fire exposure predicted in design codes such as Associação Brasileira de Normas Técnicas [28] and British Standards Institution [29], which would be that corresponding to required periods of fire resistance of 120 minutes. In this case, the results point to the need to find ways to protect masonry against fire in order to ensure safety of the structure in taller buildings.

It is noteworthy that the conditions established for these tests are the most critical regarding the strength of materials (concrete and mortar), as their resistance after cooling is lower than with the specimen still heated or even when there is simultaneous mechanical and thermal actions (considering samples heated up to the same maximum temperature), as can be observed in Abrams [32].

Figure 13 shows the stress-strain curves (relative to gross section area) of small walls before and after fire exposure, where dashed lines refer to individual specimen results and continuous lines with markers correspond to the average results.

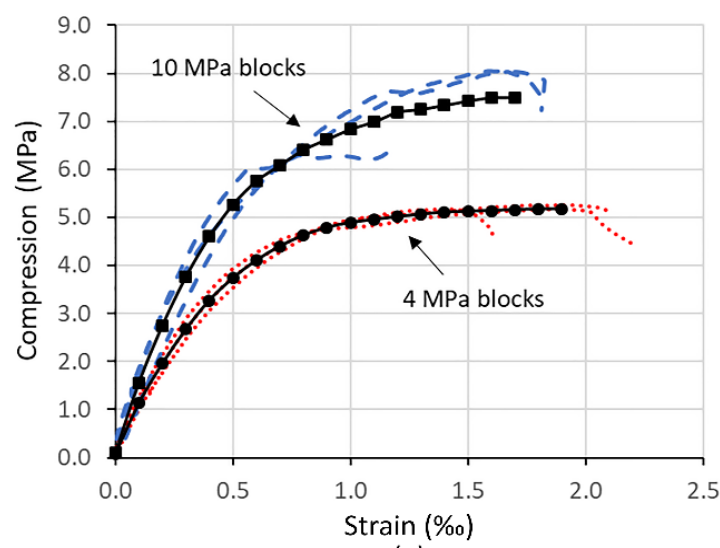

(a)

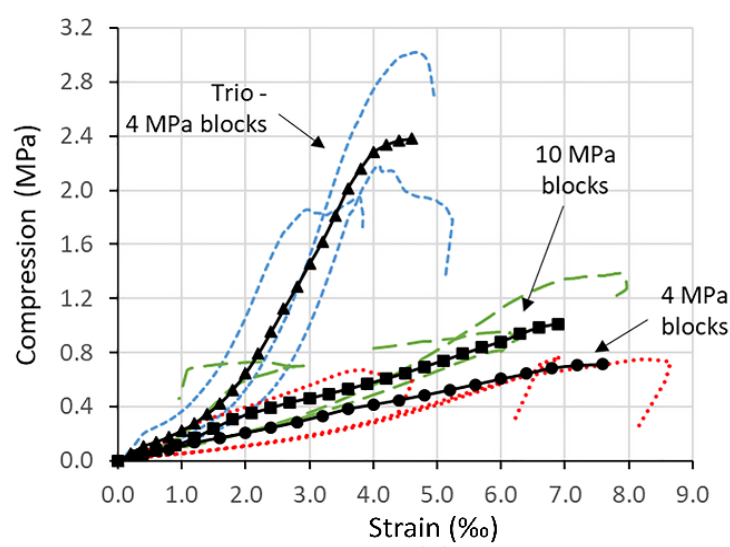

(b)

Figure 13. Stress-strain curves of small walls: (a) at room temperature; (b) after fire.

Unlike tests performed at room temperature (Figure 13a), where individual results of specimens followed a similar trend, after exposure to fire, masonry tends to show important variability in its behavior under compression (Figure 13b). Such variations are directly related to the presence of cracks, resulting from thermal expansion, which are randomly distributed along the masonry surface.

In addition to impacts on strength, exposure to high temperatures also significantly reduces the modulus of elasticity of the materials involved, resulting in reduced masonry stiffness as a whole. Table 4 presents the modulus of elasticity $\left(E_{\mathrm{p}}\right)$ values of masonry before and after fire exposure, evaluated according to requirements of Associação Brasileira de Normas Técnicas [21], that is, in the range corresponding to $5 \%$ and $30 \%$ of the failure stress. 
Table 4. Modulus of elasticity of small walls before and after the ISO 834 Standard Fire [7].

\begin{tabular}{|c|c|c|c|c|c|c|c|c|c|}
\hline \multirow[b]{2}{*}{ Blocks' nominal strength } & \multicolumn{4}{|c|}{ At room temperature } & \multicolumn{4}{|c|}{ After $70 \mathrm{~min}$ of fire exposure } & \multirow{2}{*}{$\begin{array}{c}\frac{E_{\mathrm{p}, \text { Fire }}}{E_{\mathrm{p}, \mathbf{2 0}{ }^{\circ} \mathrm{C}}} \\
(\mathbf{\%})\end{array}$} \\
\hline & $\underset{(\mathbf{M P a})}{f_{\mathrm{m}}}$ & $\begin{array}{c}\varepsilon_{\mathrm{u}} \\
(\%)\end{array}$ & $\begin{array}{l}E_{\mathrm{p}, 20^{\circ} \mathrm{C}} \\
(\mathrm{GPa})\end{array}$ & $\begin{array}{l}\text { CV } \\
(\%)\end{array}$ & $\underset{(\mathbf{M P a})}{f_{\mathrm{m}}}$ & $\varepsilon_{\mathrm{u}}(\% \mathrm{o})$ & $\begin{array}{l}E_{\text {p,Fire }} \\
(\text { GPa) }\end{array}$ & CV $(\%)$ & \\
\hline $4 \mathrm{MPa}$ & 5.20 & 1.9 & 9.50 & 8.6 & 0.73 & 7.6 & 0.12 & 76.5 & 1.3 \\
\hline $10 \mathrm{MPa}$ & 7.61 & 1.6 & 13.69 & 14.2 & 1.03 & 6.9 & 0.16 & 43.5 & 1.2 \\
\hline $4 \mathrm{MPa}$ - Trio & 5.20 & 1.9 & 9.50 & 8.6 & 2.38 & 4.6 & 0.40 & 22.4 & 4.2 \\
\hline
\end{tabular}

$f_{\mathrm{m}}$ - average compression strength of the small walls (in the gross area). $\varepsilon_{\mathrm{u}}-$ strain corresponding to the maximum stress $\left(f_{\mathrm{m}}\right) \cdot E_{\mathrm{p}, 20^{\circ} \mathrm{C}}-$ modulus of elasticity at room temperature (before fire exposure). $E_{\mathrm{p}, \mathrm{Fog}}-$ modulus of elasticity after cooling (residual). $\mathrm{CV}$ - coefficient of variation of individual results of the specimens around the mean.

Regardless of block strength, the modulus of elasticity of the masonry decreases dramatically after fire exposure on both faces, resulting in just over 1\% compared to its value at room temperature. Although it showed less reduction in its stiffness, this fact is also observed in walls with only one face exposed to fire, where the post-fire modulus of deformation resulted in only $4.2 \%$ compared to results at room temperature.

In this context, it is important to point out that, in addition to the time of fire exposure, the different types of mortar commonly used in bed and vertical joints tend to directly influence the residual stiffness of the assembly, as its degradation at high temperatures depends on its component materials, as discussed in Andreini et al. [15].

\section{CONCLUSIONS}

Considering the particular case investigated here (i.e, characteristics of the specimens regarding their geometry and materials, as well as the boundary conditions imposed in the tests), the following conclusions can be drawn:

- Variation in block strength (concretes with the same aggregate type) does not significantly change the temperature evolution along the masonry cross section.

- However, masonry tends to experience different kinds of damage according to the initial strength of block concretes. Due to thermal expansion, higher strength blocks are more susceptible to cracking; in contrast, lower strength blocks tend to show greater degradation in the mechanical properties of the material at elevated temperatures.

- Masonry has a considerable reduction in its compressive strength after exposure to fire (Standard Fire) on both faces, with residual strength around $14 \%$ compared to its strength at room temperature, after 70 minutes of exposure.

- Its performance is much better by exposure to fire on only one face, where the average residual strength resulted in the triple of walls without separating function.

- Considering the geometry of blocks analyzed, the thermal insulation criterion is reached just over 60 minutes under the ISO 834 Standard Fire [7], which can be critical for tall buildings.

- Therefore, considering the criteria of mechanical resistance and thermal insulation, the experimental results presented here indicate the need to study ways to protect masonry against fire, especially in cases of multi-storey buildings.

- Due to the proximity of the results of blocks, prisms and small walls, it can be concluded that mortar joints made with cement, lime and sand up to $1 \mathrm{~cm}$ thick do not significantly change the temperature gradient in the section compared to blocks. However, they have a considerable influence on the residual mechanical properties of masonry after fire exposure.

- Considering the good agreement between the results of prisms and small walls, the use of simpler specimens, such as two-block prisms, may lead to satisfactory results in the evaluation of temperature rise and the residual strength of masonry as a whole, taking into consideration the slenderness effects separately.

\section{ACKNOWLEDGEMENTS}

The authors acknowledge the São Paulo Research Foundation (FAPESP - grant \#2017/20255-4) for the financial support. Moreover, we acknowledge the Structural Engineering Department at the University of Sao Paulo (USP- 
EESC) for the facilities and technical support for this research and the National Council for Scientific and Technological Development (CNPq) for the research scholarship.

\section{REFERENCES}

[1] M. R. S. Corrêa "Masonry engineering in brazil past development, current overview, future improvements", in 15th Inter. Brick and Block Masonry Conf., Florianópolis, Brazil, 2012.

[2] S. Russo and F. Sciarretta, "Masonry exposed to high temperatures: Mechanical behaviour and properties - An overview," Fire Saf. J., vol. 55, pp. 69-86, Jan 2013. http://dx.doi.org/10.1016/j.firesaf.2012.10.001.

[3] European Standards, Eurocode 6 - Design of Masonry Structures - Part 1.2: General Rules - Structural Fire Design, EN 1996-12:2005, 2005.

[4] American Concrete Institute, Code Requirements for Determining Fire Resistance of Concrete and Masonry Constructions Assemblies, ACI/TMS 216.1-14, 2014.

[5] Standards Australia, Australian Standard - Masonry Structures, AS 3700-2018, 2018.

[6] F. A. Nahhas, R. A. Saada, G. Bonnet, and P. Delmotte, "Resistance to fire of walls constituted by hollow blocks: experiments and thermal modelling," Appl. Therm. Eng., vol. 27, pp. 258-267, Jan 2007. http://dx.doi.org/10.1016/j.applthermaleng.2006.04.017.

[7] International Organization for Standardization, Fire Resistance Tests - Elements of Building Construction - Part 1: General Requirements, ISO 834-1:1999, 1999.

[8] R. F. R. Lopes, J. P. C. Rodrigues, J. M. Pereira, and P. B. Lourenço, "Análise experimental de uma parede de alvenaria estrutural de blocos de concreto de três células em situação de incêndio," Concreto Construcoes, vol. 90, pp. 86-94, Apr-Jun 2018.

[9] T. Z. Harmathy and L. W. Allen, "Thermal performance of concrete masonry walls in fire," Fire Technol., vol. 8, pp. 142-148, May 1972. http://dx.doi.org/10.1007/BF02590578.

[10] A. Nadjai, M. O'Garra, F. A. Ali, and D. Laverty, "A numerical model for the behaviour of masonry under elevated temperatures," Fire Mater., vol. 27, pp. 163-182, Aug 2003. http://dx.doi.org/10.1002/fam.824.

[11] A. Nadjai, M. O'Garra, F. A. Ali, and R. Jurgen, "Compartment masonry walls in fire situations," Fire Technol., vol. 42, pp. 211231, Apr 2006. http://dx.doi.org/10.1007/s10694-006-7509-6.

[12] M. Andreini and M. Sassu, "Mechanical behaviour of full unit masonry panels under fire action," Fire Saf. J., vol. 46, pp. 440-450, Oct 2011. http://dx.doi.org/10.1016/j.firesaf.2011.07.004.

[13] T. Nguyen and F. Meftah, "Behavior of clay hollow-brick masonry walls during fire. Part 1: Experimental analysis," Fire Saf. J., vol. 52, pp. 55-64, Aug 2012. http://dx.doi.org/10.1016/j.firesaf.2012.06.001.

[14] T. Nguyen and F. Meftah, "Behaviour of hollow clay brick masonry walls during fire. Part 2: 3D finite element modelling and spalling assessment," Fire Saf. J., vol. 66, pp. 35-45, May 2014. http://dx.doi.org/10.1016/j.firesaf.2013.08.017.

[15] M. Andreini, A. D. Falco, and M. Sassu, "Stress-strain curves for masonry materials exposed to fire action," Fire Saf. J., vol. 69, pp. 43-56, Oct 2014. http://dx.doi.org/10.1016/j.firesaf.2014.08.005.

[16] S. Russo and F. Sciarretta, "Numeric research on the mechanical properties of different masonry units during and after fire", in Proc. Brick and Block Masonry: Trends, Innovations and Challenges, Modena, 2016, pp. 999-1005.

[17] W. Khaliq and M. F. Bashir, "High temperature mechanical and material properties of burnt masonry bricks," Mater. Struct., vol. 49, pp. 5195-5208, Mar 2016. http://dx.doi.org/10.1617/s11527-016-0854-0.

[18] Associação Brasileira de Normas Técnicas, Argamassa para assentamento e revestimento de paredes e tetos - Determinação do indice de consistência, ABNT NBR 13276, 2016.

[19] Associação Brasileira de Normas Técnicas, Blocos vazados de concreto simples para alvenaria - Requisitos, ABNT NBR 6136, 2016.

[20] Associação Brasileira de Normas Técnicas, Blocos vazados de concreto simples para alvenaria - Métodos de ensaio, ABNT NBR 12118, 2013.

[21] Associação Brasileira de Normas Técnicas, Alvenaria de blocos de concreto - Métodos de ensaio, ABNT NBR $16522,2016$.

[22] L. M. F. Oliveira, "Estudo teórico e experimental do comportamento das interfaces verticais de paredes interconectadas de alvenaria estrutrural,” Ph.D. thesis, Univ. S. Paulo, São Carlos, SP, Brasil, 2014. [Online]. Available: https://teses.usp.br/teses/disponiveis/18/18134/tde-30072014-085747/publico/2014DO_LucianaMarcelaFilizoladeOliveira.pdf

[23] O. S. Izquierdo, "Estudo da interface bloco/graute em elementos de alvenaria estrutural,” Ph.D. thesis, Univ. S. Paulo, São Carlos, SP, Brasil, 2015. [Online]. Available: http://web.set.eesc.usp.br/static/media/producao/2015DO_OrietaSotoIzquierdo.pdf

[24] American Society for Testing and Materials, Standard Test Method for Static Modulus of Elasticity and Poisson's Ratio of Concrete in Compression, ASTM C469/C469M-14, 2014.

[25] Associação Brasileira de Normas Técnicas, Concreto e argamassa - Determinação da resistência à tração por compressão diametral de corpos de prova cilindricos, ABNT NBR 7222, 2011. 
[26] A. H. Buchanan and A. K. Abu, Structural design for fire safety, 2nd ed. Chichester, West Sussex, United Kingdon: John Wiley \& Sons, 2018.

[27] European Standards, Eurocode 2 - Design of Concrete Structures. Part 1.2: General Rules for - Structural Fire Design, EN 1992-12:2004, 2004.

[28] Associação Brasileira de Normas Técnicas, Exigências de resistência ao fogo de elementos construtivos de edificações Procedimento, ABNT NBR 14432, 2001.

[29] British Standards Institution, Fire Safety in the Design, Management and Use of Residential Buildings - Code of Practice, BSI BS 9991, 2015.

[30] M. Henry, M. Suzuki, and Y. Kato, "Behavior of fire-damaged mortar under variable re-curing conditions," ACI Mater. J., vol. 108, pp. 281-289, Jan 2011. http://dx.doi.org/10.14359/51682493.

[31] V. Pachta, S. Triantafyllaki, and M. Stefanidou, "Performance of lime-based mortars at elevated temperatures," Constr. Build. Mater., vol. 189, pp. 576-584, Nov 2018. http://dx.doi.org/10.1016/j.conbuildmat.2018.09.027.

[32] M. S. Abrams, "Compressive strength of concrete at temperatures to 1600F," Am. Concr. Inst., Temperature and Concrete, vol. 25, pp. 33-58, 1971. ACI Special Publication.

Author contributions: DFL: Conceptualization, Data curation, Formal analysis, Funding acquisition, Investigation, Methodology, Project administration, Validation, Visualization, Writing-original draft, Writing-review \& editing; RHD: Conceptualization, Data curation, Formal analysis, Investigation, Methodology, Project administration, Validation, Visualization; JMN: Conceptualization, Data curation, Formal analysis, Funding acquisition, Investigation, Methodology, Project administration, Supervision, Validation, Visualization, Writing-review \& editing; MRSC: Conceptualization, Data curation, Formal analysis, Funding acquisition, Investigation, Methodology, Project administration, Supervision, Validation, Visualization, Writing-review \& editing.

Editors: Nigel G. Shrive, Guilherme Aris Parsekian. 